\title{
The evaluation of some physiological indices of Arabian mares during pregnancy and lactation*
}

\author{
M. Budzyńska \\ Department of Ethology and Technological Basis of Animal Production, \\ Lublin Agricultural University \\ Akademicka 13, 20-950 Lublin. Poland
}

(Received 19 November 2001; revised version 21 February 2002; accepted 9 May 2002)

\begin{abstract}
The study was carried out on 48 purebred Arabian mares in the Bialka Stud (Lublin region). Blood indicators (haematological, biochemical, immunological) and heart rate changes during blood collection were determined in the last four months of pregnancy and in six lactation months. Milk testing (bacteriological, cytological, chemical) was conducted during the entire lactation. The majority of determined indices showed significant $(P \leq 0.05)$ or highly significant $(P \leq 0.01)$ differences during pregnancy and lactation. The levels of some indices (lymphocytes, segmented neutrophils, neutrophil/lymphocyte (N/L) ratio, AST, LDH, TG, haptoglobin) were similar in the last month of pregnancy and the first lactation month so they can be classified among periparturient symptoms. The milk protein and fat contents and somatic cell count showed a decrease, whereas the lactose level slightly increased over the duration of the suckling period. Knowledge of the mares' metabolic profile and changes in emotional balance in specific physiological periods can be useful in assessing if the pregnancy and lactation are proceeding correctly, which is important for breeding success.
\end{abstract}

KEY WORDS: blood indices, milk composition, heart rate, pregnancy, lactation, Arabian mares

\section{INTRODUCTION}

Breeding success is strictly related to the proper course of pregnancy and lactation, which is why knowledge of changes in physiological indices during these periods is so important. The results of some studies (Kluczek and Zwoliński, 1978; Gill

\footnotetext{
- This study was the subject of PhD Thesis
} 
et al., 1994) indicate that pregnancy and lactation cause a significant metabolic load on the mare's body. The specificity of mares' physiological states (a long-lasting 11-month-pregnancy, 6-months-suckling period and continuous presence of the foal until weaning at the age of half a year) leads not only to metabolic changes but also influences on their emotional balance. Horse aversiveness is a behavioural feature expressing fear. Blood collection is one of the interventions causing a stressful situation that can elicit a fear response in horses. The intensity of this reaction can be determined by bchavioural signs and functional changes of organs. The heart rate is one of these changeable indices and its increase is caused by increased sympathetic nervous system (SNS) activity (Rushen et al., 1999). The aim of the study was to examine the effect of pregnancy and lactation on some physiological indices of Arabian mares.

\section{MATERIAL AND METHODS}

The studies were carried out on 48 breeding Arabian mares in the Białka Stud (Lublin region) from October to July. The studied mares were in the reproductive age, from 5 to 18 years old. All mares were kept, fed and examined under the same conditions. The animals were fed with a winter diet of oats, wheat middlings, hay and carrots and a summer diet of oats, hay and pasture according to the Nutrient Requirements for Horses (1997) respectively for pregnant and lactating mares. The mares were examined in the last four months of pregnancy (from the $8^{\text {th }}$ to $11^{\text {th }}$ month) and in six lactation months (from the $1^{\text {st }}$ to the $6^{\text {th }}$ month). The mean pregnancy duration of the studied mares was $332.5 \pm 10.1$ days. The parturitions were uneventful. Collecting of biological material (blood, milk) and pulse rate measurement were conducted on every mare in monthly intervals. The colostrum period (two first days of lactation) was excluded because of dynamic changes of mammary gland fluid (Tischner et al., 1996).

Blood samples were collected from the jugular vein. In the blood the haematological indices: haematocrit $(\mathrm{Ht})$, haemoglobin $(\mathrm{Hb})$, erythrocytes, leukocytes, neutrophils: band and segmented, eosinophils, basophils, monocytes, lymphocytes were determined by classical methods used in clinical studies (Stankicwicz, 1973). The neutrophil/lymphocyte ratio was calculated (Puppe et al., 1997). In the serum the biochemical indices: total protein, triglycerides (TG), alanine aminotransferase (ALT), asparagine aminotransferase (AST), lactate dehydrogenase (LDH) were determined spectrophotometrically using "LIQUICK CORMAY" diagnostic kits. The immunological indicators: class $\mathrm{G}$ immunoglobulins ( $\mathrm{IgG}$ ) by radial immunodifusion (Mancini et al., 1965) "BIND A RID TM" diagnostic kits, haptoglobin (Hp) by an enzymatic method using "PHASE TM RANGE" diagnostic kits, and lysozyme by a modificd spectrophotometrical method (Shugar, 1952). 
In the milk the chemical composition (protein, fat, lactose, dry matter content) was determined using a Milkoscan apparatus. The bacteria content in CFU (colony forming units)/ $\mathrm{ml}$ of milk by the Bactoscan apparatus and the somatic cell count in thousands/ml of milk using a Fossomatic apparatus, were also estimated.

The intensity of mares' aversiveness was measured by heart rate changes during blood collection. The heart rate (HR) was recorded continuously by a Hippocard-Polar Sport Tester PEH 4000 telemetric apparatus from the moment of apparatus input before the intervention until its end, apparatus output. The time of the staff entering and inserting the needle was measured individually for every mare. The analysis of HR records showed that the entry of the staff and the short skin irritation caused by needle insertion were stress factors in the studies. The heart rate (heart beats $/ \mathrm{min}$ ) in four variants (there were about $3 \mathrm{~min}$ intervals between them) : (1) before intervention, (2) on entry of staff (stableman and vet doctor), (3) at needle insertion, (4) after intervention, is given.

The results were processed statistically using SPSS software.

\section{RESULTS AND DISCUSSION}

The results of studies on blood indices are shown in Tables 1 and 2 . The haematocrit was significantly $(\mathrm{P} \leq 0.01)$ higher during late pregnancy, by $4.8 \%$, than during the suckling months. An analogous trend for horses was found by Zwoliński et al. (1965), Stankiewicz (1973) and Kluczek and Kluczek (1979). The correlation coefficients between crythrocyte count and Hb concentration and between erythrocyte count and $\mathrm{Ht}$ level were positive and statistically significant $(\mathrm{P} \leq 0.001)$.

The mean leukocyte count was very similar in both studied periods, which were also observed by Stankiewicz (1973). Pregnancy and lactation belong to factors decreasing the leukocyte count according to Stankiewicz (1973) and Gill et al. (1994), these counts increase just before and after parturition as Winnicka (1997) reports. This was confirmed in our studies and the highest values were reached in the last month of pregnancy and in the first month of lactation but also in the sixth. The white blood cell indices can be classified as the indicators of the periparturient period because of their specific changes. The level of segmented neutrophils was the highest in the last month of pregnancy and in the first month of the suckling period. For the level of lymphocytes the lowest values were found in both mentioned months. The increase in the neutrophil to lymphocyte $(\mathrm{N} / \mathrm{L})$ ratio has been reported as a reliable indictor of a stress response that was proved in studies on cattle, pigs and chickens by Gross and Siegel (1983), Stull and McDonough (1994) and Puppe et al. (1997). The $\mathrm{N} / \mathrm{L}$ ratio reached the highest values in the last month of pregnancy and the first of lactation; this reaction could have been caused by periparturient stress. 
凷

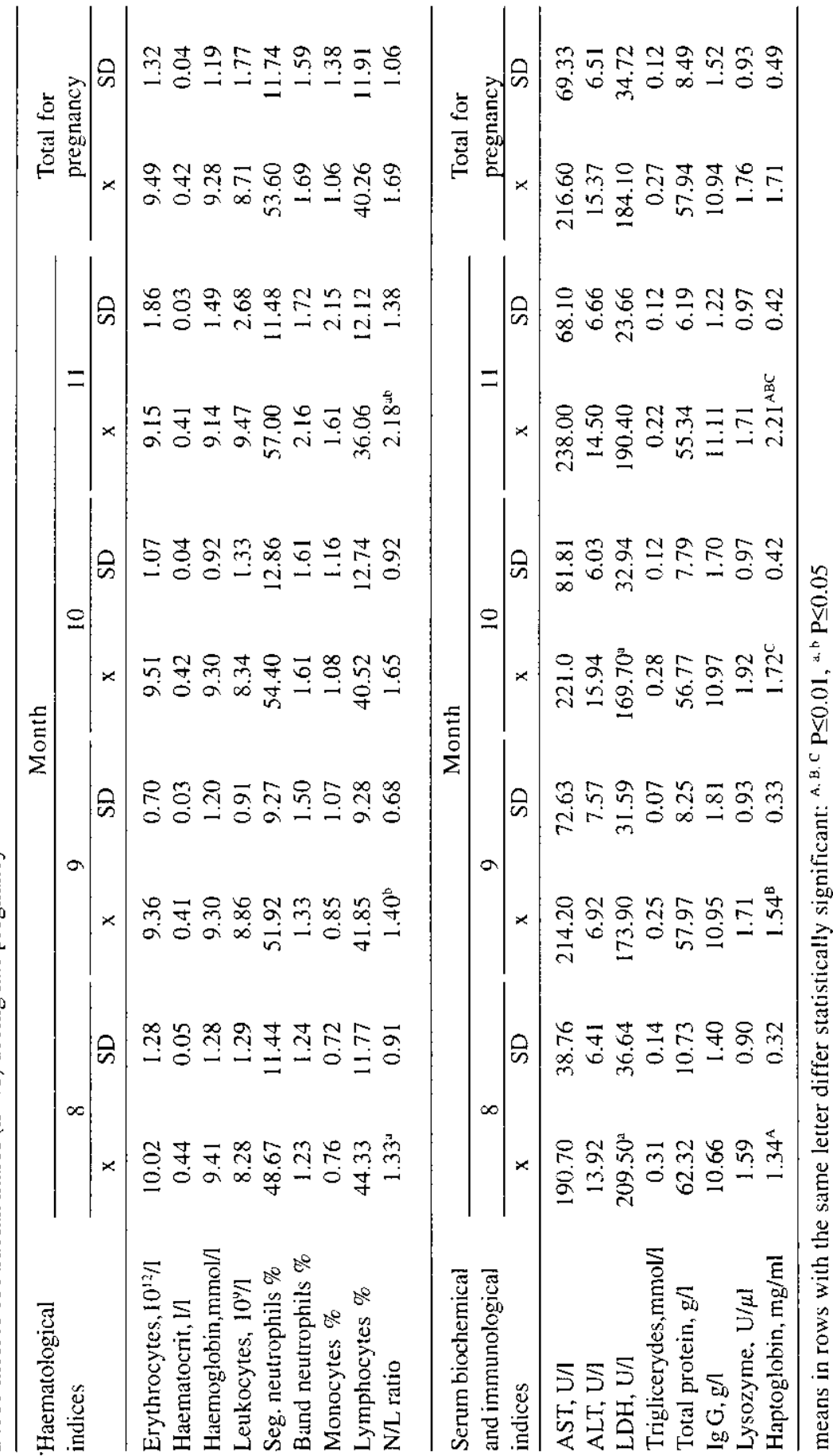




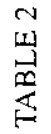

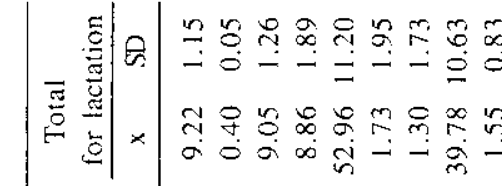

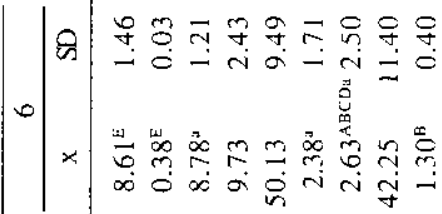

कि $\mid$

紊

$n$

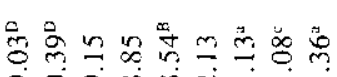

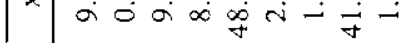

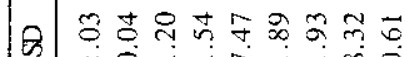

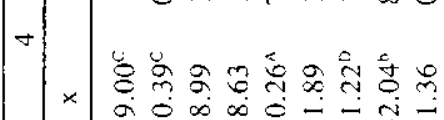

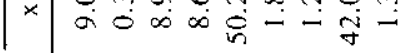

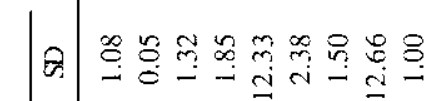
$m$

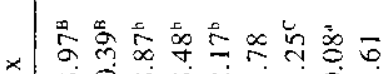

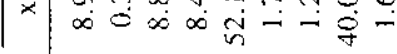

竞

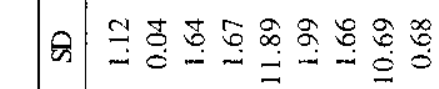

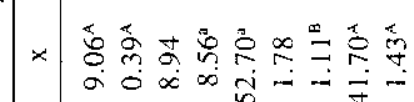

ดी

$\stackrel{\text { 㸺 }}{\Xi}$

岂

E

䨪

这

$\frac{4}{0}$

$\stackrel{3}{.}$

$\frac{8}{\circ}$

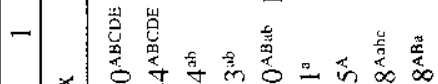

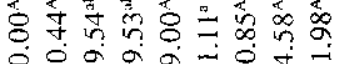

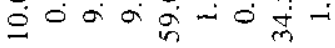

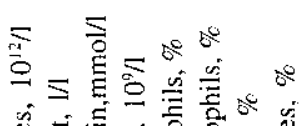

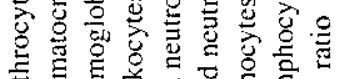

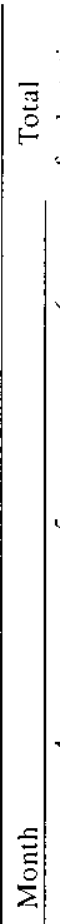

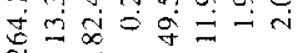
$\sim-\infty$ व

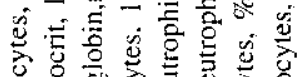

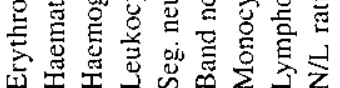

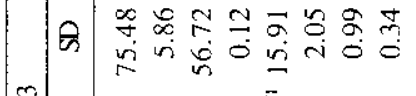

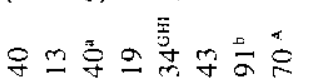

的它员二-

Im $\vec{\infty} \dot{0} \overrightarrow{0}=0$

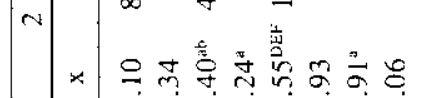

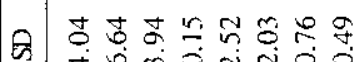

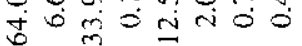

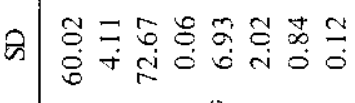

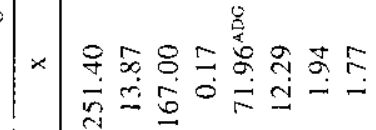

की भิ

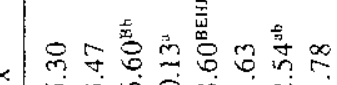

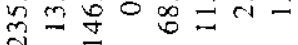

$0 \infty_{\infty}^{\infty} \approx \infty \approx 8 \%$

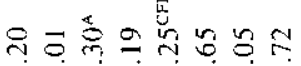

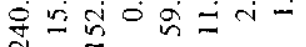
$\stackrel{2}{8}$ $-$

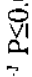
范 逽 m 茹 * $\infty$

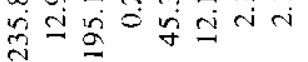
$\sum_{\grave{\Xi}}$

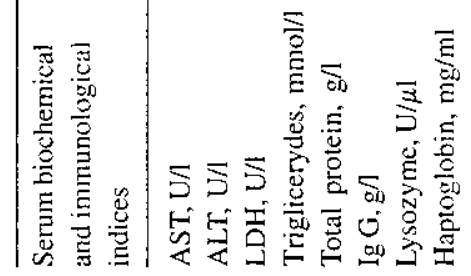
inm 
Positive, highly significant $(\mathrm{P} \leq 0.001)$ correlations between the mares' age and segmented neutrophil count $\left(r_{x y}=0.36\right)$ and between the age and $N / L$ ratio $\left(r_{x y}=0.43\right)$ were found. The segmented neutrophil count changed from $49.4 \pm 10.8$ for $5-8$ year-old mares and $52.5 \pm 8.04$ for 9 -11-year-old mares, to $64.1 \pm 11.6 \%$ for $12-18$ year-old mares in late pregnancy and $50.07 \pm 9.82,53.5 \pm 11.1$ and $60.3 \pm 11.5 \%$, respectively, in lactation (the means for the I and III age groups and the means for the II and III age groups differ at $\mathrm{P} \leq 0.01)$. The $\mathrm{N} / \mathrm{L}$ ratio changed from $1.3 \pm 0.61$ for the 5-8-year-old mares and $1.58 \pm 0.84$ for the 9 -11-year-old mares to $2.73 \pm 1.43$ for the 12-18-year-old ones in late pregnancy and $1.33 \pm 0.61,1.52 \pm 0.74$ and $2.26 \pm 1.06$, respectively, during lactation (the means for the I and III age groups and the means for the II and III age groups differ at $\mathrm{P} \leq 0.01$ ).

The mean AST activity for lactation overall was $12 \%$ higher in comparison with the mean for late pregnancy (at $\mathrm{P} \leq 0.01$ ). The difference in ALT activity was significant $(P \leq 0.05)$ and the mean for late pregnancy was higher by $13 \%$ compared with lactation overall. These results can suggest intensive protein metabolism caused by proper preparing of a pregnant mare's body for increased effort during lactation. The level of some biochemical indices such as AST, LDH and triglycerides was similar in the last pregnancy month and in the first month of lactation, therefore they could be classified as periparturient indicators.

The serum protein level decreased in the month before parturition and in the first three lactation months. The lgG level was significantly $(\mathrm{P} \leq 0.01)$ higher, by $7.4 \%$, in lactating mares. The mean lysozyme activity for total lactation was $15.4 \%$ higher $(\mathrm{P} \leq 0.05)$ than in late pregnancy. The haptoglobin concentration was $11 \%$ higher $(\mathrm{P} \leq 0.05)$ in lactating mares than in late pregnant ones. This acute phase protein reached the highest values at the end of pregnancy, in agreement with studies by Wlodarczyk-Szydłowska et al. (2000). It can be stated that the increased concentration of haptoglobin is characteristic not only of a pathological state but also of specific physiological ones, such as the periparturient period.

The means of the main milk components in particular months of lactation are shown in Table 3 . The protein and fat content was the highest in the first month whereafter it decreased until the end of lactation. A similarly high protein value for the first lactation month, 3.84\% was found by Tomczyński and Smoczyński (1982) and $4.13 \%$ by Csapo-Kiss et al. (1995). A significantly lower result, 2.5\%, was given by Leonhard (1956). The lactose content slightly increased with lactation stage, which was also shown by Leonhard (1956) and Kulisa (1980). However, Krasnova (1962) noted a decrease in lactose that according to Doreau and Boulot (1989) could be caused by mastitis - an uncommon disease in nursing mares. The somatic cell count in milk is a reliable index of mammary gland health and in mare milk it regularly decreased with lactation stage. When compared with hygienic quality in other farm animal species, mare milk had a specially high 


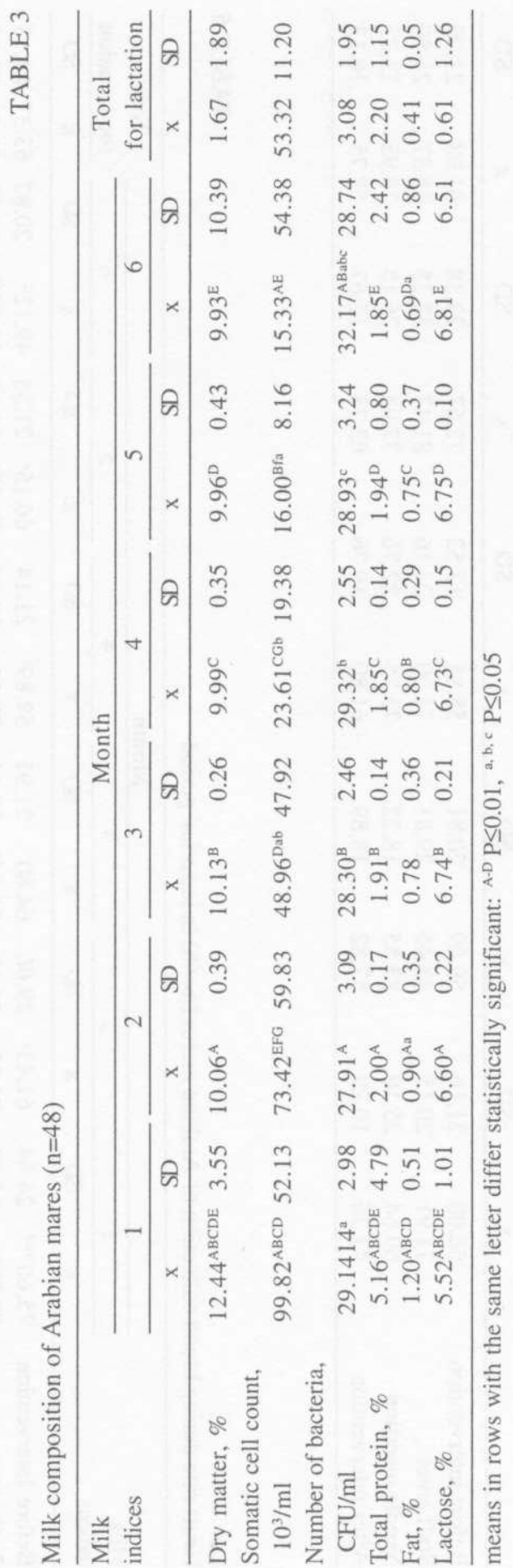



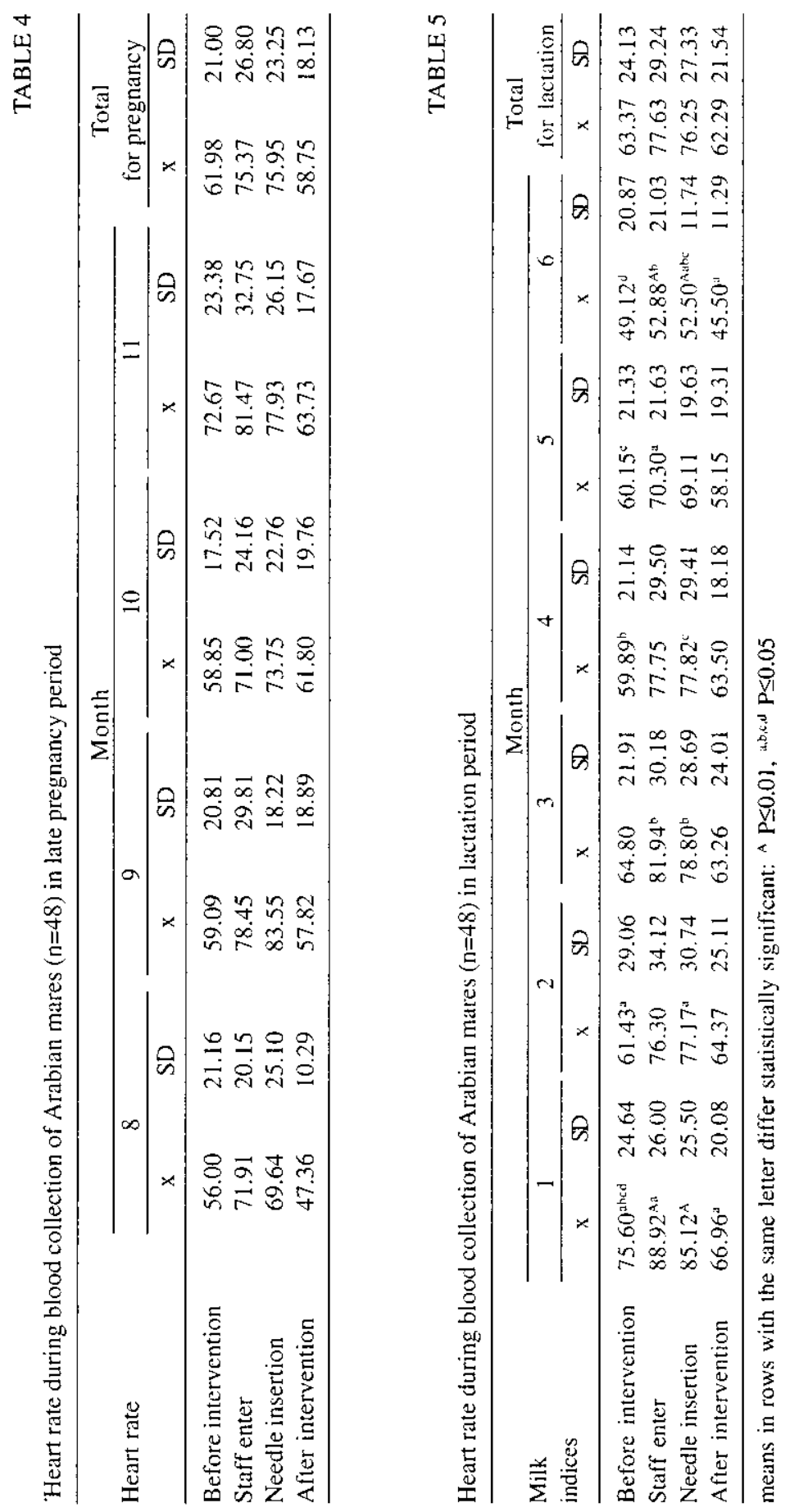
quality owing to low somatic cell counts (below $100 \times 10^{3} / \mathrm{ml}$ of milk) and low bacteria contents (not more than $35 \times 10^{3} \mathrm{CFU} / \mathrm{ml}$ of milk).

The changes in the fear reaction level based on heart rate records in four variants during blood collection in late pregnancy and lactation are shown in Tables 4 and 5 . The most intensive emotional stress in mares was caused by entry of a human, which caused an increase in the heart rate by $22.03 \%$ in relation to the mean value of the HR before blood collection. The highest heart rate in the four studied variants was recorded in the periparturient period, which can be explained by the stress before parturition and strong maternal instinct in the first phase of lactation.

\section{CONCLUSIONS}

The increased level of serum humoral immunity factors (Ig G, haptoglobin, lysozyme) during lactation indicate that this period is a significant load on the mare's body as revealed by immunological system activation.

Heart rate monitoring in mares during blood collection is useful for evaluating the emotional changes in the fear reaction during late pregnancy and lactation.

\section{REFERENCES}

Csapo-Kiss Zs., Stefler J., Martin T.G., Makray S., Csapo J., 1995. Composition of mares colostrum and milk. Protein content, amino acid composition and contents of macro- and micro- elements. Int. Dairy J. 5, 403-415

Doreau M., Boulot S., 1989. Recent knowledge on mare milk production: a review. Livest. Prod. Sci. 22, 213-235

Gill J., Flisińska-Bojanowska A., Grzelkowska K., 1994. Diurnal and seasonal changes in the WBC number, neutrophil percentage and lysozyme activity in the blood of barren, pregnant and lactating mares. Adv. Agr. Sci. 3, Fasc. 1, 15-23

Gross W.B., Siegel H.S., 1983. Evaluation of the heterophil/lymphocyte ratio as measure of stress in chicken. Avian Dis. 4, 972-977

Kluczek J.P., Kluczek E., 1979. The red blood cells indicators of foaled mares' blood (in Polish). Pr. Wydz. Nauk Przyr. BTN. PWN, Warszawa-Poznań, Ser, B 27, 3-10

Kluczek E., Zwoliński J., 1978. Total protein and its fractions in pregnant mares (in Polish). $\mathrm{Pr}$. Wydz. Nauk Przyr. BTN. PWN, Warszawa-Poznań, Ser. B 25, 49-62

Krasnova O., 1962. Chemical composition of milk from mares foaling at different seasons (in Russian). Konevodstvo i Konnyj Sport 2, 27-28

Kulisa M., 1980. The level of lactose, free glucose and galactose in Arabian mares milk (in Polish). Rocz. Nauk. Zoot. 2, 31-36

Leonhard I., 1965. About milk yield and mare milk (in Polish). Prz. hod. 33(3), 23-24 
Mancini G., Carbonara A.O., Heremans J.F.. 1965. Immunological quantitation of antigens by single radial immunodifusion. Immunochemistry 2, 235-254

Nutrient Requirements of Horses (in Polish), 1997. The Kielanowski Institute of Animal Physiology and Nutrition (Editor). Jabłonna (Poland)

Puppe B.. Tuchscherer M., Tuchscherer A., 1997. The effect of housing conditions and social environment immediately after weaning on the agonistic behaviour, neutrophil/lymphocyte ratio and plasma glucose level in pigs. Livest. Prod. Sci. 2, 157-164

Rushen J., Taylor A.A., de Passille A.M., 1999. Domestic animals' fear of humans and its effect on their welfare. Appl. Anim. Behav. Sci. 65, 283-303

Shugar D., 1952. The measurement of iysozyme activity and the ultra-violet inactivation of lysozyme. Biochim. Biophys. Acta 8, 302-309

Stankiewicz W., 1973. Veterinary Haematology (in Polish). PWRiL, Warszawa (Poland)

Stull C.L., Mc Donough P., 1994. Multidisciplinary approach to evaluating welfare of veal calves in commercial facilities. J. Anim. Sci. 72, 2518-2524

Tischner M., Niezgoda J., Wieczorek E., Mękarska A., Lisowska A., 1996. The evaluation of colostrum quality of mares (in Polish). Med. wet. 52, 381-383

Tomczyński R., Smoczyński S., 1982. Change in chemical composition of mare milk during early lactation period (in Polish). Zesz. probl. Post. Nauk rol. No. 264, 645-649

Winnicka A., 1997. The Reference Values of the Basic Laboratory Investigations in the Veterinary (in Polish). Warsaw Agricultural University Press, Warszawa (Poland)

Whodarczyk-Szydłowska A., Chełmońska-Soyta A., Nowacki W., 2000. Acute phase proteins in horses (in Polish). Zesz. Nauk. AR Wroclaw No. 390, 41-48

Zwoliński J., Ganowicz M., Siudziński S., 1965. Observation on some haematological indices of pregnant mares (in Polish). Med. wet. 21, 683-685

\section{STRESZCZENIE}

\section{Ocena wybranych wskaźników fizjologicznych u klaczy arabskich w okresie ciąży i Iaktacji}

Badania przeprowadzono u 48 klaczy czystej krwi arabskiej w Stadninie Koni w Białce (woj. lubelskie). Badania krwi (hematologiczne, biochemiczne, immunologiczne) i rejestrację zmiany tętna podczas pobierania krwi wykonano w 4 ostatnich miesiącach ciąży i w 6 miesiącach laktacji. Skład bakteriologiczny, cytologiczny oraz chemiczny mleka oznaczano podczas całej laktacji. W okresie ciąży i laktacji większość oznaczanych wskaźników różniła się istotnic $(\mathrm{P} \leq 0,05)$ lub wysoce istotnie $(\mathrm{P} \leq 0,01)$. Poziom niektórych badanych wskaźników (limfocyty, neutrofile segmentowane, stosunek neutrofile/limfocyty, AST, LDH, trójglicerydy, haptoglobina) był zbliżony w ostatnim miesiącu ciąży i w pierwszym miesiącu laktacji, co należy zaliczyć do objawów okresu okołoporodowego. Zawartość białka, tłuszczu i liczba komórck somatycznych w mleku zmniejszała się, a poziom laktozy wzrastał wraz $\mathrm{z}$ upływem laktacji.

Znajomość zmian profilu metabolicznego i emocjonalnej równowagi klaczy, badanej zmianami w akcji serca, pozwala na ocenę prawidłowości przebicgu ciąży i laktacji, co ma duże znaczenie dla uzyskania sukcesów hodowlanych. 